\title{
Revisiting the Development of Probiotic-based Functional Chocolates
}

\author{
Dimas Rahadian Aji Muhammad ${ }^{1 *}$, Endang Sutriswati Rahayu ${ }^{2,3,4}$ and Dwi Larasatie Nur Fibri ${ }^{3}$ \\ ${ }^{1}$ Department of Food Science and Technology, Faculty of Agriculture, Universitas Sebelas Maret, Jl. Ir Sutami \\ 36A Surakarta, 57126, Indonesia \\ ${ }^{2}$ Center for Food and Nutrition Studies, Universitas Gadjah Mada, Gedung PAU JL. Teknika Utara, Barek, \\ Sleman, 55281, Indonesia \\ ${ }^{3}$ Department of Food Technology and Agricultural Products, Faculty of Agricultural Technology, Universitas \\ Gadjah Mada, Jl. Flora No. 1 Bulaksumur Yogyakarta, 55281, Indonesia \\ ${ }^{4}$ University Center of Excellence for Research and Application on Integrated Probiotic Industry, Universitas \\ Gadjah Mada, Yogyakarta, 55281, Indonesia
}

\begin{abstract}
The status of chocolate as functional food is still questionable for some other people as chocolate can also give some adverse effect due to its high fat and sugar content. To overcome this issue, some attempts have made by food scientist to produce chocolate with high potential health benefits and minimum adverse effects such as by fat reduction, sugar replacement and probiotic supplementation. Some of sugar replacer are providentially identified as prebiotic substances. This review, therefore, deeply discuss the potential use of probiotics and sugar replacer in chocolate. The health benefit as well as the effect on the consumer acceptance are also covered as chocolate reformulation may result in the alteration on the chocolate characteristic. Moreover, the regulation in chocolate manufacturing and functional food from different regulatory boards are covered in this review as the guidelines to answer challenges and opportunities in developing functional chocolate. This review also clearly shows a possible direction of designing probiotic chocolate in the future that has not been fully explored until to date.
\end{abstract}

\section{Keywords \\ chocolate, probiotic, sensory, sugar replacement}

\section{Introduction}

The development of functional foods is continuously carried out by food scientists to answer global health problems and to respond consumers' needs towards healthier food products [1]. A functional food can be defined as food that has beneficial effects on health beyond basic nutritional values [2]. However, it is worth to note that the definition of functional food is still diverse among countries and regulatory boards in the world [3]. Therefore, regulations, policies and health claims of functional food vary among the countries. For instance, some countries (e.g., Canada, United States, European Union, Japan and China) permit a disease risk reduction claim of a certain food in addition to health function claim. On the contrary, a disease risk reduction claim is not allowed in Russia, India, Taiwan, Thailand, and Singapore [4]. Despite its variation, the similar points among the regulations are that functional food is that taken as part of the usual diet and has a specific health claim. 
Probiotic is widely used in the functional food formulation as it provides health benefits for human [5]. Probiotics are known as 'living microorganisms' that confer beneficial health effects on the host by improving its intestinal microbial balance if administered in an adequate amount in daily diet [6]. Probiotics may also provide other health benefits such as reducing cholesterol level, reducing blood pressure, amelioration of arthritis, facilitation of mineral absorption, protection against gastrointestinal pathogens, and enhancement of the immune system [7]. In the last few years, some studies attempted to incorporate probiotics in chocolate [8,9]. There studies are reasonable as chocolate can be an effective delivery matrix for probiotics. This is based on the fact that nowadays, chocolate becomes the most popular confectionery product throughout the world due to its good taste, unique texture, pleasant physiological effects, and association with an increase in happiness [10]. It was reported that the total consumption of chocolate reached 7.7 million metric tons in 2019 and experienced a 3.2 percent expansion of the market over the last five years [11]. This review, therefore, highlight current studies on the probiotic chocolate. Furthermore, the potential development of synbiotic chocolate by combining probiotic microorganism and prebiotic substances is also covered in this review.

\section{Brief history of chocolate}

Cocoa beans, the main material of chocolate making, are developed inside the fruit pods of the cocoa tree (Theobroma cacao L.). Cocoa is native to Central America. By the Aztecs and the Mayas, cocoa was traditionally consumed as spiced beverage and called as 'the food from the Gods' since they believed that cacao seeds were the gift from the god of wisdom and thus cocoa beverage was a source of wisdom and energy [12]. The Spanish introduced cocoa drink to Europe, successively, cocoa drink formulated with sugar and spices was being widely consumed by people from England to Italy by the mid-18th century [13].

In the Industrial Revolution era, Joseph Fry of England used a steam engine to grind cocoa beans; and then in 1828, the Dutch chemist, Van Houten, successfully separated cocoa butter from the dry cocoa solids using a hydraulic press. The cocoa solid could be ground into cocoa powder to make a better chocolate beverage. In the same period, Fry and Sons developed a process to make solid chocolate by the addition of the cocoa butter and sugar [14]. In 1847, the production of solid chocolate started in Great Britain. It was only in the early 20th century that solid chocolate became more popular than chocolate beverage. Due to the increasing demand for cocoa beans, the Portuguese, the British, and the Dutch established cocoa plantation in Africa and Asia in the areas about 20 degrees latitude north and south of the equator which are warm and have moist climates [13]. Recently, Woongnaa [15] reported that the four leading cocoa producing countries in the world were Cote d'Ivoire, Ghana, Nigeria, and Cameroon contributing about $70 \%$ of global cocoa production.

Innovative processes were found in Switzerland to improve the quality of chocolate bar. In 1897, Daniel Peter used milk powder to eliminate the perishability issue in chocolate. Nearby, the Lindt Company invented a process known as conching to create a smoother product [13]. Nowadays, the common procedure of making chocolate consists of several consecutive steps, including mixing (to mix the ingredients such as cocoa mass, cocoa butter, sugar, milk and emulsifier), refining (to reduce the particle size), conching (to fine-tune the chocolate flavour), tempering (to form the cocoa butter crystal) and moulding (to shape the chocolate) [16]. Depending on the formulation, there are three well-known basic types of chocolate in the market namely milk, dark and white chocolate. In short, milk chocolate normally contains all of the above-mentioned chocolate ingredients. Dark chocolate is formulated without milk, while white chocolate is made without cocoa mass.

Chocolates is continuously developed by the food scientists and industries, particularly in order to fulfil the demand of consumers. Some product developments focus on the incorporation of functional materials such as herbs, 
spices as well as probiotics $[17,18,19,20]$. In the effort of innovative chocolate formula, it is important to note that the food industry must still give serious attention on the regulation issued by regulatory. Knowing regulation released by the regulatory bodies of certain area where the chocolates are produced and marketed is substantial for the food industry to start reformulating chocolate recipe. Chocolate regulation regarding dark, milk and white chocolate has been stated in Codex Alimentarius (CODEX STAN 87-1981), European Parliament and the Council (Directive 2000/36/EC) and Food and Drug Administration (Code of Federal Regulations Title 21 Part 163) as shown in Table 1.

\section{Incorporation of probiotics in chocolate}

Probiotics have been successfully incorporated in various cocoa-derived products, including chocolate bar, mousse and dessert [21, 22, 23]. Chocolate can be a good probiotic carrier for intestinal delivery due to its ability to protect the bacteria from environmental stress condition (gastric acidity and bile salts) [24]. Even though phenols could act as antimicrobials, phenolic compounds in chocolate did not influence the survival of the probiotic bacteria [25].

Table 1: Chocolate regulation

\begin{tabular}{|c|c|c|c|}
\hline Type & $\begin{array}{l}\text { Codex Alimentarius } \\
\text { (CODEX STAN 87-1981) }\end{array}$ & $\begin{array}{l}\text { European Parliament and the } \\
\text { Council (Directive 2000/36/EC) }\end{array}$ & $\begin{array}{l}\text { Food and Drug Administration (Code } \\
\text { of Federal Regulations Title } 21 \text { Part } \\
163 \text { ) }\end{array}$ \\
\hline $\begin{array}{l}\text { White } \\
\text { chocolate }\end{array}$ & $\begin{array}{l}\text { a. Contains not less than } 20 \% \text { by } \\
\text { weight of cocoa butter; } \\
\text { b. Contains not less than } 14 \% \text { by } \\
\text { weight of total milk solids, } \\
\text { including } 2.5-3.5 \% \text { by weight of } \\
\text { milk fat. }\end{array}$ & $\begin{array}{l}\text { a. Contains not less than } 20 \% \\
\text { cocoa butter; } \\
\text { b. Contains not less than } 14 \% \text { dry } \\
\text { milk solids obtained by partly or } \\
\text { wholly dehydrating whole milk, } \\
\text { semi- or full-skimmed milk, } \\
\text { cream, or from partly or wholly } \\
\text { dehydrated cream, butter or milk } \\
\text { fat, of which not less than } 3.5 \% \\
\text { is milk fat. }\end{array}$ & $\begin{array}{l}\text { a. Contains not less than } 20 \% \text { by } \\
\text { weight of cocoa butter; } \\
\text { b. Contains not less than } 3.5 \% \text { by } \\
\text { weight of milk fat and not less than } \\
14 \% \text { by weight of total milk solids; } \\
\text { c. Contains not more than } 55 \% \text { by } \\
\text { weight nutritive carbohydrate } \\
\text { sweetener; } \\
\text { d. Emulsifying agents (if applied) used } \\
\text { singly or in combination, the total } \\
\text { amount of which does not exceed } \\
1.5 \% \text { by weight. }\end{array}$ \\
\hline $\begin{array}{l}\text { Milk } \\
\text { chocolate }\end{array}$ & $\begin{array}{l}\text { a. Contains at least } 25 \% \text { cocoa } \\
\text { solids, including a minimum of } \\
2.5 \% \text { fat-free solids; } \\
\text { b. Contains minimum } 14 \% \text { non-fat } \\
\text { milk solids, including } 2.5-3.5 \% \\
\text { milk fat. }\end{array}$ & $\begin{array}{l}\text { a. Contains not less than } 25 \% \text { total } \\
\text { dry cocoa solids; } \\
\text { b. Contains not less than } 14 \% \text { dry } \\
\text { milk solids obtained by partly or } \\
\text { wholly dehydrating whole milk, } \\
\text { semi- or full-skimmed milk, } \\
\text { cream, or from partly or wholly } \\
\text { dehydrated cream, butter or milk } \\
\text { fat; } \\
\text { c. Contains not less than } 2.5 \% \text { dry } \\
\text { non-fat cocoa solids; } \\
\text { d. Contains not less than } 3.5 \% \text { milk } \\
\text { fat; } \\
\text { e. Contains not less than } 25 \% \text { total } \\
\text { fat (cocoa butter and milk fat). }\end{array}$ & $\begin{array}{l}\text { a. Contains not less than } 10 \% \text { by weight } \\
\text { of cocoa liquor; } \\
\text { b. Contains not less than } 3.39 \% \text { by } \\
\text { weight of milk fat and not less than } \\
12 \% \text { by weight of total milk solids; } \\
\text { c. Emulsifying agents (if applied) used } \\
\text { singly or in combination, the total } \\
\text { amount of which does not exceed } \\
1.0 \% \text { by weight. }\end{array}$ \\
\hline $\begin{array}{l}\text { Dark } \\
\text { chocolate }\end{array}$ & $\begin{array}{l}\text { Contains not less than } 35 \% \text { total dry } \\
\text { cocoa solids, including not less than } \\
18 \% \text { cocoa butter and not less than } \\
14 \% \text { of dry non-fat cocoa solids. }\end{array}$ & $\begin{array}{l}\text { Contains not less than } 35 \% \text { total dry } \\
\text { cocoa solids, including not less than } \\
18 \% \text { cocoa butter and not less than } \\
14 \% \text { of dry non-fat cocoa solids. }\end{array}$ & - \\
\hline
\end{tabular}


Previous studies found some interesting findings in the development of probiotic chocolates (Table 2). For instance, Bacillus coagulans GBI-30, 6086 strain (10-6 to 10-8 CFU/g) were successfully added into dark chocolate at $70{ }^{\circ} \mathrm{C}$ using a mixer. This strain has been reported to have a high survival rate after digestion [8]. Konar and his research group [26] reported that Lactobacillus acidophilus and Lactobacillus paracasei at the level of $9.00 \log$ cfu per $25 \mathrm{~g}$ chocolate were successfully incorporated into white chocolate after conching. After 90 days, probiotic viability was above $6.61 \mathrm{log} \mathrm{cfu} / 25 \mathrm{~g}$ which L. acidophilus showed higher levels of viability than L. paracasei. Another study within a similar group research showed that in milk chocolate, the probiotics viability was above 5.90 $\log \mathrm{cfu} / 25 \mathrm{~g}$ which L. acidophilus showed higher levels of viability than L. paracasei after 90 days storage [27]. Interestingly, Rad et al. [9] reported that $L$. casei 431 -incorporated milk chocolates could be stored at $20^{\circ} \mathrm{C}$ for 6 months. However, Probiotic viability was better in chocolate that was stored at $4{ }^{\circ} \mathrm{C}$ than $20^{\circ} \mathrm{C}$. Encapsulated $L$. plantarum ( $10 \mathrm{~g}$ of encapsulated probiotics $/ \mathrm{kg}$ of chocolate) were also incorporated into the chocolate at an additional mixing step after tempering. After 60 days and 180 days, the probiotics viability was $8.00 \mathrm{log} \mathrm{cfu} / \mathrm{g}$ and over $6.00 \mathrm{log} \mathrm{cfu} / \mathrm{g}$ up, respectively [28].

Different bacteria, such as L. rhamnosus, L. paracasei F19, L. casei DG and L. reuteri DSM17938: were incorporated into molten dark chocolate. After 90 days, the probiotics viability was above $6.00 \mathrm{log} \mathrm{cfu} / 15 \mathrm{~g}$ except L. reuteri DSM17938 which was below $6.00 \mathrm{log}$ cfu/15 g [25]. Almost in the same period, Silva et al. [29] reported that semi-sweet chocolate increased the survival of L. acidophilus LA3 and Bifidobacterium animalis subsp. Lactis BLC1 under gastrointestinal conditions with high viability. Kemsawasd et al. [30] also showed that chocolate can protect L. casei 01 and L. acidophilus LA5 in the stomach and small intestine conditions. According to Yonejima [31], chocolate is an effective matrix to deliver probiotics in a viable form to the intestine because acid tolerance of probiotic bacteria was higher by coating in with the chocolate. Probiotics that were incorporated in chocolate were more stable against gastric acid condition than probiotics powder.

Probiotics has been successfully added into chocolates. Nevertheless, it is noteworthy that until to date the living microorganism used in probiotic chocolate or other food products is bacteria. The species of Bacillus Sp., Lactobacillus Sp. and Bifidobacterium Sp. are the most dominant probiotic bacteria studied in chocolate formulation $[32,33,34]$. Probiotic could be incorporated in chocolate in the freeze dried or microencapsulated form to obtain optimal viability in the gastrointestinal system (Table 2). The probiotic substance may be added to chocolate in the additional mixing process either before or after tempering [29, 31]. Recently, a yeast species Saccharomyces boulardii has been reported to have specific probiotic properties $[35,36]$. To the best of our knowledge, no study on the application of the yeast in chocolate has been initiated. It might be an interesting topic for the future study.

\section{Reducing adverse effect of chocolate: fat reduction and sugar replacement}

There are many studies showing the potential health benefit of probiotic chocolate, and thus the prospect of probiotic chocolate as functional food product. Yet, the status of probiotic chocolate as functional food may be questioned by some people. According to Raymond and his co-worker [37], the controversy of chocolate status as functional food is strongly related to its fat content. Even though chocolate with probiotics is proven to have beneficial effect on health, high intake of fat is still strongly associated with some negative implications, such as cardiovascular diseases, high cholesterol and high blood pressure [38]. In addition to the fat content, sugar (sucrose) content may be one of the major concerns of the scientists. On one hand, sugar has a significant contribution in chocolate properties mainly as sweetener and bulking agent [39]. Moreover, sugar has been reported to be able to enhance flavanols absorption in the gastrointestinal track [40]. However, on the other hand, high consumption of sugar triggers some health problems such as obesity, diabetes and dental health [41]. Some efforts need to be 
Table 2: Probiotic enrichment in chocolate

\begin{tabular}{|c|c|c|c|}
\hline Probiotic enrichment & $\begin{array}{c}\text { Type of } \\
\text { chocolate }\end{array}$ & Important findings & Reference \\
\hline Lactobacillus casei 431 & $\begin{array}{c}\text { milk } \\
\text { chocolate }\end{array}$ & $\begin{array}{l}\text { a. Probiotic milk chocolates could be stored at } 20{ }^{\circ} \mathrm{C} \text { for } 6 \text { months. } \\
\text { However, Probiotic viability was better in chocolate that was stored at } \\
4{ }^{\circ} \mathrm{C} \text { than } 20{ }^{\circ} \mathrm{C} \text {. } \\
\text { b. Probiotic sucrose-free chocolate had satisfactory sensory attributes and } \\
\text { higher viscosity than control chocolate. }\end{array}$ & [79] \\
\hline $\begin{array}{l}\text { Bacillus coagulans } \\
\text { GBI-30, } 6086 \text { strains }\end{array}$ & $\begin{array}{c}\text { dark } \\
\text { chocolate }\end{array}$ & $\begin{array}{l}\text { Probiotic microorganisms }\left(10^{-6} \text { to } 10^{-8} \mathrm{CFU} / \mathrm{g}\right) \text { were successfully added } \\
\text { into dark chocolate at } 70{ }^{\circ} \mathrm{C} \text { using a mixer. Bacillus coagulans GBI-30, } \\
6086 \text { strains had a high survival rate after digestion. Probiotic dark } \\
\text { chocolates had a similar sensory characteristic to chocolate control. }\end{array}$ & [8] \\
\hline $\begin{array}{l}\text { Lyophilised } L . \\
\text { paracasei and } L \text {. } \\
\text { acidophilus }\end{array}$ & $\begin{array}{c}\text { white } \\
\text { chocolate }\end{array}$ & $\begin{array}{l}\text { a. Probiotic microorganisms }(9.00 \log \mathrm{cfu} / 25 \mathrm{~g}) \text { were successfully } \\
\text { incorporated into white chocolate after conching. After } 90 \text { days, probiotic } \\
\text { viability was above } 6.61 \log \mathrm{cfu} / 25 \mathrm{~g} \text { which } L \text {. acidophilus showed higher } \\
\text { levels of viability than } L \text {. paracasei. } \\
\text { b. The incorporation of the probiotics had no significant effect on the water } \\
\text { activity, textural properties and melting profile and resulted in a tolerable } \\
\text { change on the rheological properties and colour of the chocolate. }\end{array}$ & [26] \\
\hline $\begin{array}{l}\text { Encapsulated } \\
\text { Lactobacillus } \\
\text { plantarum }\end{array}$ & $\begin{array}{c}\text { dark } \\
\text { chocolate }\end{array}$ & $\begin{array}{l}\text { a. Probiotic microorganisms ( } 10 \mathrm{~g} \text { of encapsulated probiotics } / \mathrm{kg} \text { of } \\
\text { chocolate) were incorporated into the chocolate at an additional mixing } \\
\text { step after tempering. After } 60 \text { days and } 180 \text { days, the probiotics viability } \\
\text { was } 8.00 \mathrm{log} \text { cfu } / \mathrm{g} \text { and over } 6.00 \mathrm{log} \mathrm{cfu} / \mathrm{g} \text { up, respectively. } \\
\text { b. Probiotics incorporation had no significant effect on volatile profiles, } \\
\text { aroma, texture and appearance of chocolate of the chocolate after } 180 \\
\text { days of storage. }\end{array}$ & [28] \\
\hline $\begin{array}{l}\text { Lactobacillus } \\
\text { acidophilus and } L . \\
\text { paracasei }\end{array}$ & $\begin{array}{c}\text { milk } \\
\text { chocolate }\end{array}$ & $\begin{array}{l}\text { a. Probiotic microorganisms }(9.00 \log \text { cfu } / 25 \mathrm{~g}) \text { were incorporated into milk } \\
\text { chocolate after conching. After } 90 \text { day, the probiotics viability was above } \\
5.90 \log \text { cfu } / 25 \mathrm{~g} \text { which } L \text {. acidophilus showed higher levels of viability } \\
\text { than } L \text {. paracasei. } \\
\text { b. The incorporation of the probiotics had no significant effect on the } \\
\text { particle size, hardness, and melting profile, and limited effects on water } \\
\text { activity, moisture content, rheological properties and colour of the } \\
\text { chocolate. }\end{array}$ & [27] \\
\hline $\begin{array}{l}\text { Lactobacillus } \\
\text { rhamnosus, } L . \\
\text { paracasei } \mathrm{F} 19, L . \\
\text { casei } \mathrm{DG} \text { and } L . \\
\text { reuteri } \mathrm{DSM} 17938 \\
\end{array}$ & $\begin{array}{c}\text { dark } \\
\text { chocolate }\end{array}$ & $\begin{array}{l}\text { a. Probiotic microorganisms were incorporated into molten dark chocolate. } \\
\text { After } 90 \text { days, the probiotics viability was above } 6.00 \log \mathrm{cfu} / 15 \mathrm{~g} \text { except } \\
\text { L. reuteri DSM } 17938 \text { which was below } 6.00 \log \mathrm{cfu} / 15 \mathrm{~g} \text {. } \\
\text { b. The incorporation of the probiotics had no significant effect on the } \\
\text { sensory profile and water activity of the chocolate }\end{array}$ & [25] \\
\hline $\begin{array}{l}\text { Lactobacillus } \\
\text { acidophilus } \text { LA3 and } \\
\text { Bifidobacterium } \\
\text { animalis subsp. Lactis } \\
\text { BLC1 }\end{array}$ & $\begin{array}{l}\text { semi-sweet } \\
\text { chocolate }\end{array}$ & $\begin{array}{l}\text { a. Semi-sweet chocolate increased bacterial survival under gastrointestinal } \\
\text { conditions with high viability. } \\
\text { b. After } 120 \text { days of storage, fat bloom occurred in the probiotic-enriched } \\
\text { chocolate and the control. } \\
\text { c. Probiotic chocolates had a high acceptability by panellists. }\end{array}$ & [29] \\
\hline $\begin{array}{l}\text { Lactobacillus } \\
\text { acidophilus } \mathrm{NCFM}, \\
\text { Lactobacillus } \\
\text { rhamnosus } \mathrm{HN} 001 \text {, } \\
\text { and Bifidobacterium } \\
\text { lactis } \mathrm{HN} 019\end{array}$ & $\begin{array}{c}\text { milk } \\
\text { chocolate }\end{array}$ & $\begin{array}{l}\text { a. Inoculation of the probiotics bacteria in milk chocolate at } 40{ }^{\circ} \mathrm{C} \text { resulted } \\
\text { in higher scores of overall sensory qualities, lower viscosity and less } \\
\text { increase in volume than that at } 35^{\circ} \mathrm{C} \text {. } \\
\text { b. After } 6 \text { months of storage, the survival of } L \text {. acidophilus NCFM and } L \text {. } \\
\text { rhamnosus HN001 strains was above } 90 \% \text {, with a viable cell count of } \\
\text { about } 8.1 \log \text { CFU/g). }\end{array}$ & [63] \\
\hline $\begin{array}{l}\text { Immobilized } \\
\text { Lactobacillus casei } 01 \\
\text { and L. acidophilus } \\
\text { LA5 powder }\end{array}$ & $\begin{array}{l}\text { white, milk } \\
\text { and dark } \\
\text { chocolates }\end{array}$ & $\begin{array}{l}\text { a. Chocolate protected L. casei } 01 \text { and L. acidophilus LA5 in the stomach } \\
\text { and small intestine conditions. } \\
\text { b. Probiotic powders had no significant effect on sensory attributes. } \\
\text { However, after } 60 \text { days storage, overall liking scores significantly } \\
\text { decreased in all the chocolate samples. }\end{array}$ & [30] \\
\hline
\end{tabular}


Table 2: Probiotic enrichment in chocolate (continued)

\begin{tabular}{|c|c|c|c|}
\hline Probiotic enrichment & $\begin{array}{c}\text { Type of } \\
\text { chocolate }\end{array}$ & Important findings & Reference \\
\hline $\begin{array}{l}\text { Freeze-dried } \\
\text { Lactobacillus } \\
\text { acidophilus } N C F M \circledR \\
\text { and Bifidobacterium } \\
\text { lactis HNO19 powders }\end{array}$ & $\begin{array}{l}\text { milk and } \\
\text { dark } \\
\text { chocolate }\end{array}$ & $\begin{array}{l}\text { a. Lb. acidophilus } \mathrm{NCFM} \AA \text { and } B \text {. lactis } \mathrm{HN} 019 \text { were added after } \\
\text { tempering process and were able to survive during manufacturing } \\
\text { process and storage period ( } 14 \text { months). } \\
\text { b. Lb. acidophilus } \mathrm{NCFM} \AA \text { and } B \text {. lactis } \mathrm{HN} 019 \text { incorporated in chocolate } \\
\text { had high numbers of viable cells in the intestinal system. } \\
\text { c. To create a sensorial acceptable chocolate, the incorporation of } L \text {. } \\
\text { acidophilus } \mathrm{NCFM} \AA \text { and } B \text {. lactis HN019 should be between } 2 \times 10^{8}- \\
2 \times 10^{9} \mathrm{CFU} / \mathrm{g} \text { in total. }\end{array}$ & {$[80]$} \\
\hline $\begin{array}{l}\text { Freeze-dried } \\
\text { Lactobacillus } \\
\text { acidophilus NCFM® } \\
\text { and Bifidobacterium } \\
\text { lactis HN019 }\end{array}$ & $\begin{array}{l}\text { milk and } \\
\text { dark } \\
\text { chocolate }\end{array}$ & $\begin{array}{l}\text { a. L. acidophilus NCFM }{ }^{\circledR} \text { and } \text { B. lactis } \mathrm{HN} 019 \text { had good viability in milk } \\
\text { and dark chocolate. } \\
\text { b. The chocolate was effective to preserve a high level of cell activity } \\
\text { during } 180 \text { days of storage. The probiotic-enriched chocolates could be } \\
\text { stored at room temperature without a significant decline in product } \\
\text { functionality. } \\
\text { c. The incorporation of freeze-dried L. acidophilus } \mathrm{NCFM} \circledast \text { and } B \text {. lactis } \\
\text { HN019 did not lead to a substantial disruption of the sensory properties. }\end{array}$ & [65] \\
\hline $\begin{array}{l}\text { Lactobacillus brevis } \\
\text { subsp. Coagulans } \\
\text { (Labre) FERM BP- } \\
4693 \text { and L. brevis } \\
\text { NTM003 (NTM003) } \\
\text { NITE BP-1634 }\end{array}$ & $\begin{array}{c}\text { milk } \\
\text { chocolate }\end{array}$ & $\begin{array}{l}\text { a. Chocolate was an effective matrix to deliver probiotics in a viable form } \\
\text { to the intestine. } \\
\text { b. Probiotics that were incorporated in chocolate were more stable against } \\
\text { gastric acid condition than probiotics powder. }\end{array}$ & {$[31]$} \\
\hline $\begin{array}{l}\text { Freeze-dried } \\
\text { Lactobacillus } \\
\text { rhamnosus R0011 }\end{array}$ & $\begin{array}{c}\text { dark } \\
\text { chocolate }\end{array}$ & $\begin{array}{l}\text { The incorporation of freeze-dried L. rhamnosus R0011 in dark chocolate } \\
\text { at } 40^{\circ} \mathrm{C} \text { resulted in a loss of viable cells of approximately } 0.2 \text { log per g. }\end{array}$ & [37] \\
\hline $\begin{array}{l}\text { Synbiotic, consisting } \\
\text { of lyophilised Bacillus } \\
\text { indicus HU36 and } \\
\text { dietary fibre }\end{array}$ & $\begin{array}{c}\text { dark } \\
\text { chocolate } \\
\text { couverture }\end{array}$ & $\begin{array}{l}\text { a. The addition of carboxymethylcellulose, inulin, wheat fibre, and apple } \\
\text { fibre showed a negative effect on taste, mouthfeel, texture and overall } \\
\text { acceptability. Maltodextrin and lemon fibre were chosen as the most } \\
\text { suitable dietary fibre types for further studies. } \\
\text { b. To obtain the best organoleptic properties of the product, the lemon } \\
\text { fibre concentration should be kept constant at } 1.5 \mathrm{~g} / 100 \mathrm{~g} \text { chocolate, } \\
\text { while maltodextrin concentration should be maintained at } 3.20-3.91 \\
\mathrm{~g} / 100 \mathrm{~g} \text { chocolate } \\
\text { c. B. indicus HU36 can be used efficiently for probiotic bitter chocolate } \\
\text { production. Microbiological analysis proved the Bacillus indicus HU36 } \\
\text { had a high survival rate in dark chocolate, and all inoculated samples } \\
\text { showed desired probiotic bacteria load (over } 5 \operatorname{logs} \mathrm{CFU} / \mathrm{g} \text { product). }\end{array}$ & [32] \\
\hline $\begin{array}{l}\text { Lactobacillus } \\
\text { plantarum (isolated } \\
\text { from fermented cocoa } \\
\text { beans) }\end{array}$ & $\begin{array}{c}\text { dark } \\
\text { chocolate }\end{array}$ & $\begin{array}{l}\text { a. After } 3 \text { months of storage, L. plantarum viability decreased from } 8 \text { to } 6 \\
\text { log CFU/g } \\
\text { b. The addition of potential probiotic bacteria did not impair } \mathrm{pH} \text {, colour, } \\
\text { hardness and water activity of the dark chocolate compared to the } \\
\text { control. } \\
\text { c. Dark chocolate containing probiotic bacteria had a higher viscosity than } \\
\text { the control and decreased during storage. }\end{array}$ & [64] \\
\hline $\begin{array}{l}\text { Free and encapsulated } \\
\text { Lactobacillus casei } \\
\text { NCDC } 298 \text { and inulin }\end{array}$ & $\begin{array}{c}\text { milk } \\
\text { chocolate }\end{array}$ & $\begin{array}{l}\text { a. Encapsulation had no significant impact on the survival of probiotic } \\
\text { bacteria in milk chocolate during storage at refrigeration conditions, in } \\
\text { contrast to at gastrointestinal environment. } \\
\text { b. The sensory properties of the chocolates were unchanged due to the } \\
\text { minimum metabolic activity of the bacteria during storage. }\end{array}$ & [81] \\
\hline
\end{tabular}


Please cite this article as

Muhammad et al. Reviews in Agricultural Science, 9: 233-248, 2021

https://dx.doi.org/10.7831/ras.9.0_233

Table 2: Probiotic enrichment in chocolate (continued)

\begin{tabular}{|c|c|c|c|}
\hline Probiotic enrichment & $\begin{array}{c}\text { Type of } \\
\text { chocolate }\end{array}$ & Important findings & Reference \\
\hline $\begin{array}{l}\text { Lyophilized } \\
\text { Lactobacillus casei } \\
\text { and Lactobacillus } \\
\text { paracasei. Alternative } \\
\text { sweetener (isomalt- } \\
\text { aspartame) }\end{array}$ & $\begin{array}{c}\text { milk } \\
\text { chocolate }\end{array}$ & $\begin{array}{l}\text { a. The addition of lyophilised Lactobacillus cells in chocolate did not } \\
\text { change either the total or the volatile acidity, but increased its Casson } \\
\text { viscosity, yield value and increased the hardness of the milk chocolate. } \\
\text { b. The supplementation did not change the sensorial attributes of } \\
\text { chocolate. } \\
\text { c. The number of live cells of Lactobacillus was kept at a relatively stable } \\
\text { level for } 12 \text { months at } 18^{\circ} \mathrm{C} \text { (the survival above } 85 \% \text { ). However, more } \\
\text { bacteria cells survived in chocolate stored in a refrigerated condition. }\end{array}$ & {$[82]$} \\
\hline $\begin{array}{l}\text { A mixture of } \\
\text { microencapsulated } \\
\text { Lactobacillus } \\
\text { helveticus } \text { CNCM I- } \\
1722 \text { and } \\
\text { Bifidobacterium } \\
\text { longum } \text { CNCM I-3470 }\end{array}$ & $\begin{array}{c}\text { milk and } \\
\text { dark } \\
\text { chocolate }\end{array}$ & $\begin{array}{l}\text { Chocolate protected } L \text {. helveticus and B. longum from environmental } \\
\text { stress condition. Milk chocolate was more effective than the dark one } \\
\text { (respectively } 91 \% \text { and } 80 \% \text { of survival for L. helveticus and B. longum) } \\
\text { when evaluated in Simulator of Human Intestinal Microbial Ecosystem } \\
\text { (SHIME). }\end{array}$ & {$[33]$} \\
\hline $\begin{array}{l}\text { Powdered yoghurt } \\
\text { containing } \\
\text { Streptococcus } \\
\text { thermophilus MK-10 } \\
\text { and Lactobacillus } \\
\text { delbrueckii subsp. } \\
\text { bulgaricus } 151 \\
\end{array}$ & $\begin{array}{c}\text { milk and } \\
\text { dark } \\
\text { chocolate }\end{array}$ & $\begin{array}{l}\text { a. The incorporation of the bacteria did not lead to a substantial disruption } \\
\text { of the sensory properties. } \\
\text { b. After } 6 \text { months of storage (at the temperature of } 4{ }^{\circ} \mathrm{C} \text { and } 18{ }^{\circ} \mathrm{C} \text { ), the } \\
\text { viability of the bacteria significantly decreased which } S \text {. thermophiles } \\
\text { MK-10 had a better viability than L. delbrueckii subsp. bulgaricus } 151 \text {. } \\
\text { Dark chocolate provided a better environment for the survival of the } \\
\text { bacteria. }\end{array}$ & [34] \\
\hline
\end{tabular}

undertaken by food technologists to produce high-quality chocolate with reduced fat and calories [42]. In order to develop innovative chocolate with an improved nutritional profile fat reduction and sugar replacement techniques can be carried out.

Fat reduction or fat replacement in chocolate have been conducted by different research groups. Fat reduction in chocolate was initially conducted for economical purpose since the price of the cocoa fat is relatively expensive in the market. In nutritional perspective, reducing fat content in a chocolate formula is beneficial to lessen the adverse effects of the chocolate. Reducing fat content is beneficial as it can significantly reduce the total calorie content of the chocolate. The fat-reduced chocolate can be prepared using the protocol of Do et al. [43]. Cocoa particles (defatted cocoa powder containing fat below than $1 \% \mathrm{w} / \mathrm{w}$ ) were incorporated into the chocolate formula containing molten cocoa butter, milk powder, sugar and lecithin at the level of $8.1 \%(\mathrm{w} / \mathrm{w})$. In the other studies, fat-reduced chocolate can be prepared by replacing the fat content using other materials such as hydrogenated oils, inulin, $\beta$ glucan, xanthan gum and guar gum $[44,45,46]$. However, it is notable that up till now, most of the studies discussed the impact of fat reduction or fat replacement on the quality attributes of the chocolates. As such, the fat reduction in the study of Do et al. [43] focused only on the flow properties of the modified chocolate, but did not discuss the nutritional aspect. Thus, investigation on the effect of fat-reduced chocolate on the health are still fairly absent and thus there is still a great opportunity to study this particular topic.

Various studies have also been conducted aiming to investigate the applicability of alternative sweeteners and bulking agents in chocolate. According to Saputro et al. [16], one of the main purposes of the use of sugar replacer is targeting to produce chocolate with lower glycemic index than standard chocolate, accordingly having a minimal negative health effect. The combination of high-intensity sweeteners such as sucralose, stevioside, thaumatin and sugar alcohols with a bulking agent such as inulin, maltodextrin, and polydextrose has been widely used to replace sucrose in chocolate [39,47]. It was reported that sugar replacement has significant impact on the quality of chocolate including particle size, flow behaviour, appearance, texture and melting profile as well as moisture content 
Please cite this article as

Muhammad et al. Reviews in Agricultural Science, 9: 233-248, 2021

https://dx.doi.org/10.7831/ras.9.0_233

Table 3: Impact of sugar replacement on the quality attributes of chocolate

\begin{tabular}{|c|c|c|c|c|c|c|c|c|c|}
\hline \multirow{2}{*}{ Sugar replacer } & \multirow{2}{*}{$\begin{array}{l}\text { Chocolate } \\
\text { type }\end{array}$} & \multicolumn{7}{|c|}{ Results (compared to chocolate control) } & \multirow[b]{2}{*}{ Ref. } \\
\hline & & $\begin{array}{l}\text { Particle } \\
\text { size }\end{array}$ & Viscosity & $\begin{array}{l}\text { Yield } \\
\text { stress }\end{array}$ & Lightness & Hardness & $\begin{array}{l}\text { Moisture } \\
\text { content }\end{array}$ & Other & \\
\hline \multicolumn{10}{|c|}{ Inulin } \\
\hline Inulin & & & $\uparrow$ & $\uparrow$ & & $\uparrow$ & & Sensory profile 1 & {$[68,69]$} \\
\hline $\begin{array}{l}\text { Inulin and } \\
\text { maltodextrin }\end{array}$ & & & & & & $\uparrow$ & & Sensory profile 1 & {$[70]$} \\
\hline Inulin & $\begin{array}{l}\text { White } \\
\text { chocolate }\end{array}$ & & 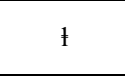 & & $\leftrightarrow$ & $\downarrow$ & & $\begin{array}{l}\text { Water activity } \downarrow \\
\text { Melting point } \leftrightarrow\end{array}$ & {$[20]$} \\
\hline $\begin{array}{l}\text { Inulin and } \\
\text { stevia with } \\
\text { different } \\
\text { rebaudioside A }\end{array}$ & $\begin{array}{l}\text { Bittersweet } \\
\text { chocolate }\end{array}$ & & & & & & & Sensory profile $\neq$ & {$[71]$} \\
\hline $\begin{array}{l}\text { Inulin with } \\
\text { steviol } \\
\text { glycosides }\end{array}$ & $\begin{array}{l}\text { Dark } \\
\text { chocolate }\end{array}$ & & $\uparrow$ & $\downarrow$ & & & & & {$[16]$} \\
\hline $\begin{array}{l}\text { Inulin with } \\
\text { polydextrose } \\
\text { and thaumatin }\end{array}$ & $\begin{array}{l}\text { Dark } \\
\text { chocolate }\end{array}$ & & $\uparrow$ & $\downarrow$ & $\downarrow$ & $\downarrow$ & $\uparrow$ & $\begin{array}{l}\text { Melting point } \leftrightarrow \\
\text { Thixotropy } \downarrow\end{array}$ & {$[72]$} \\
\hline $\begin{array}{l}\text { Inulin with } \\
\text { polydextrose } \\
\text { and stevia }\end{array}$ & $\begin{array}{l}\text { Dark } \\
\text { chocolate }\end{array}$ & & $\uparrow$ & $\downarrow$ & $\downarrow$ & $\downarrow$ & $\uparrow$ & $\begin{array}{l}\text { Melting point } \leftrightarrow \\
\text { Thixotropy } \downarrow\end{array}$ & {$[72]$} \\
\hline $\begin{array}{l}\text { Inulin with fine } \\
\text { sugar }\end{array}$ & $\begin{array}{l}\text { Milk } \\
\text { chocolate }\end{array}$ & $\uparrow$ & $\downarrow$ & $\downarrow$ & $\leftrightarrow$ & $\leftrightarrow$ & & Water activity $\downarrow$ & {$[42]$} \\
\hline Inulin & $\begin{array}{l}\text { Dark } \\
\text { chocolate }\end{array}$ & $\uparrow$ & $\uparrow$ & $\downarrow$ & $\downarrow$ & $\uparrow$ & $\uparrow$ & & {$[73]$} \\
\hline $\begin{array}{l}\text { Inulin with } \\
\text { isomalt }\end{array}$ & $\begin{array}{l}\text { Milk } \\
\text { chocolate }\end{array}$ & $\leftrightarrow$ & $\uparrow$ & $\downarrow$ & $\leftrightarrow$ & $\leftrightarrow$ & & Water activity $\leftrightarrow$ & {$[47]$} \\
\hline $\begin{array}{l}\text { Inulin with } \\
\text { malitol }\end{array}$ & $\begin{array}{l}\text { Milk } \\
\text { chocolate }\end{array}$ & $\leftrightarrow$ & $\uparrow$ & $\downarrow$ & $\uparrow$ & $\leftrightarrow$ & & Water activity $\leftrightarrow$ & {$[47]$} \\
\hline $\begin{array}{l}\text { Inulin } \\
\text { with sucralose }\end{array}$ & $\begin{array}{l}\text { Milk } \\
\text { chocolate }\end{array}$ & & & & & $\downarrow$ & $\uparrow$ & & {$[74]$} \\
\hline \multicolumn{10}{|c|}{ Polydextrose } \\
\hline $\begin{array}{l}\text { Polydextrose } \\
\text { with steviol } \\
\text { glycosides }\end{array}$ & $\begin{array}{l}\text { Dark } \\
\text { chocolate }\end{array}$ & & $\uparrow$ & $\downarrow$ & & & & & {$[75]$} \\
\hline Polydextrose & $\begin{array}{l}\text { Dark } \\
\text { chocolate }\end{array}$ & $\leftrightarrow$ & $\leftrightarrow$ & $\uparrow$ & $\downarrow$ & $\uparrow$ & $\uparrow$ & & {$[73]$} \\
\hline $\begin{array}{l}\text { Polydextrose } \\
\text { with inulin, } \\
\text { maltodextrin, } \\
\text { stevia, and } \\
\text { whey protein }\end{array}$ & $\begin{array}{l}\text { Milk } \\
\text { chocolate }\end{array}$ & $\uparrow$ & 1 & $\downarrow$ & $\downarrow$ & 1 & $\uparrow$ & $\begin{array}{l}-\quad \text { Energy value } \downarrow \\
-\quad \text { Consumer } \\
\text { acceptance } \downarrow\end{array}$ & {$[61]$} \\
\hline $\begin{array}{l}\text { Polydextrose } \\
\text { with sucralose }\end{array}$ & $\begin{array}{l}\text { Milk } \\
\text { chocolate }\end{array}$ & & & & & $\downarrow$ & $\uparrow$ & & {$[74]$} \\
\hline $\begin{array}{l}\text { Polydextrose, } \\
\text { sucralose, } \\
\text { stevioside, and } \\
\text { whey protein } \\
\text { concentrate }\end{array}$ & $\begin{array}{l}\text { Milk } \\
\text { chocolate }\end{array}$ & & & & & & & $\begin{array}{l}\text { Consumer } \\
\text { acceptance } \downarrow\end{array}$ & {$[60]$} \\
\hline
\end{tabular}


Please cite this article as

Muhammad et al. Reviews in Agricultural Science, 9: 233-248, 2021

https://dx.doi.org/10.7831/ras.9.0_233

Table 3: Impact of sugar replacement on the quality attributes of chocolate (continued)

\begin{tabular}{|c|c|c|c|c|c|c|c|c|c|}
\hline \multirow{2}{*}{ Sugar replacer } & \multirow{2}{*}{$\begin{array}{c}\text { Chocolate } \\
\text { type }\end{array}$} & \multicolumn{7}{|c|}{ Results (compared to chocolate control) } & \multirow{2}{*}{ Ref } \\
\hline & & $\begin{array}{l}\text { Particle } \\
\text { size }\end{array}$ & Viscosity & $\begin{array}{l}\text { Yield } \\
\text { stress }\end{array}$ & Lightness & Hardness & $\begin{array}{c}\text { Moisture } \\
\text { content }\end{array}$ & Other & \\
\hline \multicolumn{10}{|c|}{ Others } \\
\hline Xilitol & & $\uparrow$ & $\uparrow$ & $\uparrow$ & & $\uparrow$ & $\uparrow$ & & {$[76]$} \\
\hline Maltitol & & $\uparrow$ & $\uparrow$ & $\uparrow$ & & $\uparrow$ & $\uparrow$ & & {$[76]$} \\
\hline $\begin{array}{l}\text { Galactooligosac } \\
\text { charide }\end{array}$ & & $\uparrow$ & $\uparrow$ & $\uparrow$ & & $\uparrow$ & $\uparrow$ & & {$[76]$} \\
\hline Palm sugar & $\begin{array}{l}\text { Dark } \\
\text { chocolate }\end{array}$ & & & & & & & Aroma 1 & [59] \\
\hline $\begin{array}{l}\text { Malitol and } \\
\text { xylitol }\end{array}$ & $\begin{array}{l}\text { Milk } \\
\text { chocolate }\end{array}$ & & ‡ & 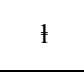 & & & & & {$[77]$} \\
\hline $\begin{array}{l}\text { Sucralose and } \\
\text { stevia }\end{array}$ & $\begin{array}{l}\text { White } \\
\text { chocolate }\end{array}$ & & & & $\leftrightarrow$ & & & Melting point $\uparrow$ & {$[78]$} \\
\hline Palm sugar & $\begin{array}{l}\text { Dark } \\
\text { chocolate }\end{array}$ & $\uparrow$ & $\uparrow$ & f & $\leftrightarrow$ & & $\uparrow$ & $\begin{array}{ll}\text { - } & \text { Melting point } \leftrightarrow \\
\text { - } & \text { Agglomeration } \uparrow \\
\text { - } & \text { Aroma } 1 \\
\end{array}$ & {$[16]$} \\
\hline $\begin{array}{l}\text { Coarse palm } \\
\text { sugar }\end{array}$ & $\begin{array}{l}\text { Dark } \\
\text { chocolate }\end{array}$ & $\uparrow$ & f & f & $\uparrow$ & $\uparrow$ & $\uparrow$ & $\begin{array}{l}\text { - Melting point } \leftrightarrow \\
\text { - Agglomeration } \uparrow \\
\text { - Thixotropy } \uparrow\end{array}$ & {$[16]$} \\
\hline $\begin{array}{l}\text { Coarse coconut } \\
\text { sugar }\end{array}$ & $\begin{array}{l}\text { Dark } \\
\text { chocolate }\end{array}$ & $\uparrow$ & 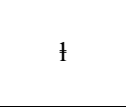 & $\downarrow$ & $\uparrow$ & $\uparrow$ & $\uparrow$ & $\begin{array}{l}\text { - Melting point } \leftrightarrow \\
\text { - Agglomeration } \uparrow \\
\text { - Thixotropy } \uparrow\end{array}$ & {$[16]$} \\
\hline $\begin{array}{l}\text { Fructooligosacc } \\
\text { haride and } \\
\text { malitol with } \\
\text { rebaudioside A }\end{array}$ & $\begin{array}{l}\text { White } \\
\text { chocolate }\end{array}$ & & & & & & & Sweetness $\leftrightarrow$ & {$[49]$} \\
\hline $\begin{array}{l}\text { Fructooligosacc } \\
\text { haride and } \\
\text { malitol with } \\
\text { sucralose }\end{array}$ & $\begin{array}{l}\text { White } \\
\text { chocolate }\end{array}$ & & & & & & & Sweetness $\leftrightarrow$ & {$[49]$} \\
\hline Malitol & $\begin{array}{l}\text { Milk } \\
\text { chocolate }\end{array}$ & & & & & & & Consumer acceptance $\downarrow$ & {$[62]$} \\
\hline $\begin{array}{l}\text { Fructose with } \\
\text { various } \\
\text { combinations of } \\
\text { highly intensive } \\
\text { sweetener and } \\
\text { bulking agent }\end{array}$ & $\begin{array}{l}\text { Semi-sweet } \\
\text { chocolate }\end{array}$ & $\uparrow$ & & & & $\uparrow$ & & Antioxidant activity $\downarrow$ & {$[66]$} \\
\hline $\begin{array}{l}\text { Maltodextrin } \\
\text { with sucralose }\end{array}$ & $\begin{array}{l}\text { Milk } \\
\text { chocolate }\end{array}$ & & & & & $\downarrow$ & $\uparrow$ & & {$[74]$} \\
\hline
\end{tabular}

sensory profile (Table 3). Research by Akyol et al. [48] investigated the replacement of sugar in dark and milk chocolate using $\beta$-glucan. However, their study only focused on short-term satiety and energy intake of respondents. With increasing demand for chocolate with energy load reduction, more investigation in this particular area is essential. Thus, until to date most of the previous studies focus on the technological aspect and scarcely on the effect of sugar replacement on the nutritional aspect.

As afore-mentioned, the combination of high-intensity sweeteners and a bulking agent has been widely used to replace sucrose in chocolate [39,47]. Interestingly, some of those sugar replacers are widely recognised as prebiotic 
substances that can induce the growth or the activity of probiotic microorganisms $[49,50]$. The chocolate that contains the combination of prebiotic substances and probiotic microorganism is termed as synbiotic chocolate. In addition to the fact that cocoa fibre has a role as prebiotic substance [51], the current studies on sugar replacement in chocolate lead a bigger opportunity for scientists to develop a more purposeful prebiotic or synbiotic chocolate. This is indeed one of the advantages of carrying out sugar replacement in chocolate that can be further explored in future studies. Also, it indicates that there is still a great opportunity for food scientist to develop synbiotic chocolate.

\section{Impact of formula modification on the quality attributes and the consumer acceptance of chocolate}

It has been broadly acknowledged that a modification of a recipe of food can have significant impacts on its quality and accordingly its consumer acceptance level. This is true as well in the case of chocolate. As well-stressed by Saputro et al. [16], there are at least six important quality attributes in chocolate, including flavour, texture, appearance, flow behaviour, melting profile and particle size distribution. In addition, the presence of moisture significantly affects the quality of the chocolate.

Some cases in chocolate production with fat reduction, sugar replacement or functional ingredients enrichment have been found by different research groups. In technological viewpoint, it has been reported that a fat-reduced chocolate (containing $24.5 \%$ of fat) had satisfactory flow properties [43]. However, fat reduction can give some drawbacks in the quality attributes of the chocolate since the cocoa fat can play significant role on the flavour release due to its ability to construct lipophilic flavour interaction, the chocolate's texture due to its functionality to form fat crystal, the chocolate's flow behaviour due to its ability to aid the cocoa particles when they flow past each other and even the chocolate's appearance (lightness) since the crystalline network of cocoa fat scatters light reducing luminance and saturation [52, 53, 54].

Several research groups replaced fat in chocolate using other materials Rodriguez Furlán et al. [46] demonstrated a substitution of fat using hydrogenated oils at a concentration of $20 \%(w / w)$. However, the effect of the substitution is not clear because they did not use conventional chocolate as the control. In the other reports, a change in the textural properties of the chocolate was observed as a result of a fat replacement. The presence of inulin and $\beta$-glucan concentrate decreased the hardness of the chocolates and undeniably, it changed the 'snap' characteristic of the chocolate [44]. In general, a lower level of the lipid phase in chocolate formulation resulted in a less hard chocolate due to its less crystalline network. Moreover, in the case of fat replacement using inulin or $\beta$ glucan, the crystalline network could not perfectly coat all the solid particles in the chocolate matrix resulting in rupture structure. On the contrary, fat replacement by using xanthan gum and guar gum blend exhibited a harder texture [45]. They hypothesised that the incorporation of hydrocolloids can induce a network of protein in the chocolate matrix contributing to the increase of the chocolate hardness.

The impact of fat reduction or replacement is not only on the quality attribute of the chocolate, but also the consumer acceptance. Rezende et al. [44], for example, reported that a low-fat chocolate with inulin and $\beta$-glucan had a lower hedonic score on the panellists' acceptance. Replacing the cocoa fat using another vegetable fat (at the equal total content) has also significant impacts on the physical, rheological and sensorial properties as well as the appearance of the chocolate during storage due to the difference of fat bloom occurrence [55]. The changing in consumer acceptance might be a serious problem, particularly in the context of the product's marketing. Nonetheless, according to Stubenitsky et al. [56], giving information to the consumers about the correlation between lower fat content and health could increase consumer acceptance to the product. This can be an alternative strategy for the food industry to promote fat-reduced chocolate. 
Similarly, sugar replacement using high intensity sweeteners in combination with bulking agent causes alteration on the characteristic of chocolate to some extent (Table 3). Even though some studies mentioned in Table 3 are not in the topic of probiotic chocolate, the results clearly indicate that reformulation of chocolate can really give significant impact when applied further in probiotic chocolates. According to Konar et al. [42], for instance, some types of sugar replacer, such as inulin, has a water binding activity resulting in a chocolate with a higher moisture content. A similar phenomenon was found when palm sugar was used as sugar replacer in dark chocolate $[57,58]$. The increase of moisture content in chocolate influences further on the other quality attributes of the chocolate, such as rheological behaviour and textural properties. Moisture on sugar particle surface increases friction among particles and promotes aggregation to form sugar network; and at the same time the moisture reduces the availability of "free" fat which is beneficial for a swift flow since more fat is used to coat the increased size of the sugar particles resulting in a more viscous chocolate $[52,58]$. The sugar network can strengthen the particle-toparticle network system in the chocolate matrix and therefore resulting in a harder chocolate. In addition to the rheology and the hardness, it has been reported that the use of sugar replacement using palm sap sugar also affected the aroma profile and the appearance of the dark chocolate [59]. Change in the quality attributes due to sugar replacement can result in the decrease of the consumer acceptance to the chocolate. As reported in the previous studies, consumers prefer the sensory properties of conventional chocolate to low sugar chocolate [60, 61]. Interestingly, in the report of Markey et al. [62], sugar-reduced chocolate obtained a higher consumer acceptance score than the conventional chocolate suggesting that there is an opportunity of the success of the low sugar chocolate in the market.

The impacts of probiotic enrichment in chocolate have been revealed in previous researches. For instance, Succi et al. [25] reported that the incorporation of L. acidophilus and L. paracasei has limited effects on water activity, moisture content, rheological properties and colour of the chocolate. Another study showed that inoculation of $L$. acidophilus $\mathrm{NCFM}{ }^{\circledR}$, L. rhamnosus $\mathrm{HN} 001$, and Bifidobacterium lactis $\mathrm{HN} 019$ in milk chocolate resulted in a lower viscosity [63]. Also, dark chocolate containing probiotic bacteria has been reported to have a higher viscosity than the control [64]. In the study of Nebesny et al. [34], it has been reported that the addition of lyophilised Lactobacillus cells in chocolate increased its Casson viscosity, yield value and increased the hardness of the milk chocolate.

Nevertheless, recently scientists also found that chocolate with probiotics is acceptable. As such, sucrose-free chocolate enriched with $L$. casei 431 have been reported to have satisfactory sensory attributes and higher viscosity than control chocolate [9]. Probiotic dark chocolates formulated with B. coagulans GBI-30, 6086 strains had a similar sensory characteristic to chocolate control [8]. Also, the incorporation of the probiotics has no significant effect on the water activity, textural properties and melting profile and results in a tolerable change on the rheological properties and colour of the chocolate [26]. Incorporation of encapsulated $L$. plantarum also has no significant effect on volatile profiles, aroma, texture and appearance of chocolate of the chocolate after 180 days of storage [28]. Kemsawasd et al. [30], who worked with probiotic powders, reported that the addition of probiotic powders had no significant effect on sensory attributes of chocolate. Also as reported by Lalicic-Petronijevic et al. [65], the incorporation of freeze-dried L. acidophilus $\mathrm{NCFM} \circledR$ and B. lactis HN019 did not lead to a substantial disruption of the sensory properties.

\section{Concluding remarks and future perspectives}

Innovations in the chocolate industry generally aim to improve the product quality and to fulfil the consumer demands for healthy food. It was shown that chocolate is an excellent carrier for oral delivery of some functional ingredients, including probiotics and prebiotics. Adding probiotics and prebiotics in a chocolate formula are the 
practical way to produce functional chocolate. Even though some people still question the claim of health benefits of chocolate, the combination of the technological application of fat reduction, sugar replacement, and functional material enrichment can be an alternative approach to produce chocolate with high potential health benefits and minimal adverse effects.

The chocolate reformulation may result in the alteration on characteristics and consumer acceptance of the chocolate. Those impacts must be taken into consideration by the food technologists when developing an innovative chocolate. Sensory properties are the primary factor that plays a key role in consumer acceptance and widely recognised as a critical success factor for the market development of food product. Nevertheless, this does not rule out the possibility to make an acceptable functional chocolate as there are already some examples of successful healthier chocolate in the market. Chocolates enriched with glucomannan, insoluble cocoa fibres, multivitamin and probiotic as well as whey chocolate sweetened with non-sucrose sweetener are the examples of former commercial functional chocolates $[22,66]$. In the case of low sugar chocolate, food industry can conduct a gradual sugar reduction in the marketed low sugar product to adjust acceptable consumer sweetness levels [67]. This approach may help the food industry to maintain the consumer acceptance and to market the low sugar chocolate.

This paper demonstrates future opportunities for new research focusing on formulating a healthier chocolate product using various potential probiotic bacteria and prebiotic substances. The modification of chocolate formula has clear advantages regarding the functional properties of the product. However, the effects on the quality attributes and the sensory properties must be taken into account. Also, serious attention should be paid on the regulation issued by regulatory bodies in the development of innovative formula of functional chocolates.

\section{Conflict of Interest}

The authors declare that they have no conflict of interest.

\section{Acknowledgement}

The authors thank the Ministry of Research and Technology/National Research and Innovation Agency, the Republic of Indonesia, for supporting this research within the scheme of Penelitian Perguruan Tinggi Badan Hukum $(P T N B H)($ No. 8/E1/KPT/2021; Contract No. 221.1/UN27.22/HK.07.00/2021).

\section{REFERENCES}

[1] Kaur N and Singh DP (2017) Deciphering the consumer behaviour facets of functional foods: A literature review. Appetite, 112: $167-187$.

[2] Wong AYT, Lai JMC and Chan AWK (2015) Regulations and protection for functional food products in the United States. J. Funct. Foods, 17: 540-551.

[3] Muhammad DRA and Dewettinck K (2017) Cinnamon and its derivatives as potential ingredient in functional food-A review. Int. J. Food Prop., 20: 2237-2263.

[4] Malla S, Hobbs JE and Sogah EK (2013) Functional foods and natural health products regulation in Canada and arouns the world: nutrition labels and health claims Saskatoon, Saskatchewan, Canada: Report prepared for the Canadian Agricultural Innovation and Regulation Network, 1-92.

[5] Frakolaki G, Giannou V, Kekos D and Tzia C (2021) A review of the microencapsulation techniques for the incorporation of probiotic bacteria in functional foods. Crit. Rev. Food Sci. Nutr., 61(9): 1515-1536.

[6] Mohammadmoradi S, Javidan A and Kordi J (2014) Boom of probiotics: This time non- alcoholic fatty liver disease - A mini review. J. Funct. Foods, 11: 30-35. 
[7] Miremadi F, Sherkat F and Stojanovska L (2016) Hypocholesterolaemic effect and anti- hypertensive properties of probiotics and prebiotics: A review. J. Funct. Foods, 25: 497-510.

[8] Kobus-Cisowska J, Szymanowska D, Maciejewska P et al. (2019) Enriching novel dark chocolate with Bacillus coagulans as a way to provide beneficial nutrients. Food Funct., 10(2): 997-1006.

[9] Rad AH, Pirouzian HR, Toker OS and Konar N (2020) Effect of various bulk sweeteners on the survivability of Lactobacillus casei 431 in milk Chocolate: Rheological and sensory properties analysis. Curr. Pharm. Biotechnol., 21(12): 1224-1231.

[10] Meier BP, Noll SW and Molokwu OJ (2017) The sweet life: The effect of mindful chocolate consumption on mood. Appetite, 108: $21-27$.

[11] Conway J (2017) Leading chocolate consuming countries worldwide 2017 | Statista. Global chocolate consumption per capita in 2017, by country. Accessed July 19, 2021. https://www.statista.com/statistics/819288/worldwide-chocolate-consumption-bycountry/

[12] Montagna MT, Diella G, Triggiano F et al. (2019) Chocolate, "food of the gods": History, science, and human health. Int. J. Environ. Res. Public Health, 16(24): 1-21.

[13] Cidell JL and Alberts HC (2006) Constructing quality: The multinational histories of chocolate. Geoforum, 37(6): $999-1007$.

[14] Bonjean CA and Brun JF (2016) Concentration and price transmission in the cocoa- Chocolate chain. In: The economics of chocolate (Squicciarini, M. P., \& Swinnen, J. Eds.). 339-362. Oxford University Press. Oxford.

[15] Wongnaa CA, Apike IA, Babu S, Awunyo-Vitor D and Kyei AB (2021) The impact of adoption of artificial pollination technology in cocoa production: Evidence from Ghana. J. Agric. Food Res., 100208.

[16] Saputro AD, Van de Walle D, Aidoo RP et al. (2017) Quality attributes of dark chocolates formulated with palm sap-based sugar as nutritious and natural alternative sweetener. Eur. Food Res. Technol., 243(2): 177-191.

[17] Muhammad DRA, Gonzalez CG, Sedaghat Doost A, Van de Walle D, Van der Meeren P and Dewettinck K (2019) Improvement of antioxidant activity and physical stability of chocolate beverage using colloidal cinnamon nanoparticles. Food Bioprocess Technol., 12: 976-989.

[18] Muhammad DRA, Lemarcq V, Alderweireldt E et al. (2020) Antioxidant activity and quality attributes of white chocolate incorporated with Cinnamomum burmannii Blume essential oil. J. Food Sci. Technol., 57(5): 1731-1739.

[19] Muhammad DRA, Tuenter E, Patria GD, Foubert K, Pieters L and Dewettinck K (2021) Phytochemical composition and antioxidant activity of Cinnamomum burmannii Blume extracts and their potential application in white chocolate. Food Chem., 340: $1-8$.

[20] Konar N, Toker OS, Rasouli Pirouzian H et al. (2018) Enrichment of milk chocolate by using epa and dha originated from various origins: effects on product quality. Sugar Tech., 20(6): 745-755.

[21] Cardarelli HR, Aragon-Alegro LC, Alegro JHA, De Castro IA and Saad SMI (2008) Effect of inulin and Lactobacillus paracasei on sensory and instrumental texture properties of functional chocolate mousse. J. Sci. Food Agric., 88(8): 1318-1324.

[22] Gadhiya D, Patel AR and Prajapati JB (2015) Current trend and future prospective of functional probiotic milk chocolates and related products - A review. Czech J. Food Sci., 33(4): 295-301.

[23] Valencia MS, Salgado SM, Andrade SAC, Padilha VM, Livera AVS and Stamford TLM (2016) Development of creamy milk chocolate dessert added with fructo-oligosaccharide and Lactobacillus paracasei subsp. paracasei LBC 81. LWT - Food Sci. Technol., 69: 104-109.

[24] Konar N, Toker OS, Oba S and Sagdic O (2016) Improving functionality of chocolate: A review on probiotic, prebiotic, and/or synbiotic characteristics. Trends Food Sci. Technol., 49: 35-44.

[25] Succi M, Tremonte P, Pannella G et al. (2017) Survival of commercial probiotic strains in dark chocolate with high cocoa and phenols content during the storage and in a static in vitro digestion model. J. Funct. Foods., 35: 60-67.

[26] Konar N, Palabiyik I, Toker OS et al. (2018) Conventional and sugar-free probiotic white chocolate: Effect of inulin DP on various quality properties and viability of probiotics. J. Funct. Foods, 43: 206-213.

[27] Toker OS, Genc Polat D, Gulfidan OG et al. (2017) Stability of lactic acid bacteria in synbiotic sugared and sugar-free milk chocolates. Int. J. of Food Prop., 20(52): 51354-51365.

[28] Mirković M, Seratlić S, Kilcawley K, Mannion D, Mirković N and Radulović Z (2018) The sensory quality and volatile profile of dark chocolate enriched with encapsulated probiotic Lactobacillus plantarum bacteria. Sensors, 18: 1-16. 
Please cite this article as

Muhammad et al. Reviews in Agricultural Science, 9: 233-248, 2021

https://dx.doi.org/10.7831/ras.9.0_233

[29] Silva MP, Tulini FL, Marinho JFU et al. (2017) Semi sweet chocolate as a vehicle for the probiotics Lactobacillus acidophilus LA3 and Bifidobacterium animalis subsp. lactis BLC1: Evaluation of chocolate stability and probiotic survival under in vitro simulated gastrointestinal conditions. LWT - Food Sci. Technol., 75: 640-647.

[30] Kemsawasd V, Chaikham P and Rattanasena P (2016) Survival of immobilized probiotics in chocolate during storage and with an in vitro gastrointestinal model. Food Biosci., 16: 37-43.

[31] Yonejima Y, Hisa K, Kawaguchi M et al. (2015) Lactic acid bacteria-containing chocolate as a practical probiotic product with increased acid tolerance. Biocatal Agric. Biotechnol, 4(4): 773-777.

[32] Erdem Ö, Gültekin-Özgüven M, Berktaş I et al. (2014) Development of a novel synbiotic dark chocolate enriched with Bacillus indicus HU36, maltodextrin and lemon fiber: Optimization by response surface methodology. LWT - Food Sci. Technol., 56(1): 187-193.

[33] Possemiers S, Marzorati M, Verstraete W and Van de Wiele T (2010) Bacteria and chocolate: A successful combination for probiotic delivery. Int. J. Food Microbiol., 141(1-2): 97-103.

[34] Nebesny E, Żyżelewicz D, Motyl I and Libudzisz Z (2005) Properties of sucrose-free chocolates enriched with viable lactic acid bacteria. Eur. Food Res. Technol., 220(3-4): 358-362.

[35] Czerucka D, Piche T and Rampal P (2007) Review article: Yeast as probiotics - Saccharomyces boulardii. Aliment Pharmacol. Ther., 26(6): 767-778.

[36] Moslehi-Jenabian S, Pedersen LL and Jespersen L (2010) Beneficial effects of probiotic and food borne yeasts on human health. Nutrients, 2(4): 449-473.

[37] Raymond Y and Champagne CP (2015) The use of flow cytometry to accurately ascertain total and viable counts of Lactobacillus rhamnosus in chocolate. Food Microbiol., 46: 176-183.

[38] Dieter BP and Tuttle KR (2017) Dietary strategies for cardiovascular health. Trends Cardiovasc Med., 27(5): $295-313$.

[39] Aidoo RP, Depypere F, Afoakwa EO and Dewettinck K (2013) Industrial manufacture of sugar-free chocolates - Applicability of alternative sweeteners and carbohydrate polymers as raw materials in product development. Trends Food Sci. Technol., 32(2): 84-96.

[40] Mellor DD, Amund D, Georgousopoulou E and Naumovski N (2018) Sugar and cocoa: sweet synergy or bitter antagonisms. Formulating cocoa and chocolate products for health: a narrative review. Int. J. Food Sci. Technol., 53(1): 33-42.

[41] Edwards CH, Rossi M, Corpe CP, Butterworth PJ and Ellis PR (2016) The role of sugars and sweeteners in food, diet and health: Alternatives for the future. Trends Food Sci. Technol., 56: 158-166.

[42] Konar N, Özhan B, Artik N, Dalabasmaz S and Poyrazoglu ES (2014) Rheological and physical properties of Inulin-containing milk chocolate prepared at different process conditions. CYTA-, J. Food, 12(1): 55-64.

[43] Do TAL, Vieira J, Hargreaves JM, Mitchell JR and Wolf B (2011) Structural characteristics of cocoa particles and their effect on the viscosity of reduced fat chocolate. LWT -, Food Sci. Technol., 44(4): 1207-1211.

[44] Rezende NV., Benassi MT, Vissotto FZ, Augusto PPC and Grossmann MVE (2015) Effects of fat replacement and fibre addition on the texture, sensory acceptance and structure of sucrose- free chocolate. Int. J. Food Sci. Technol., 50(6): 1413-1420.

[45] Amir IZ, Sharon WXR and Syafiq A (2013) D-optimal mixture design on melting and textural properties of dark chocolate as affected by cocoa butter substitution with xanthan gum/guar gum blends. Int. Food Res. J., 20(4): 1991-1995.

[46] Rodriguez Furlán LT, Baracco Y, Lecot J, Zaritzky N and Campderrós ME (2017) Influence of hydrogenated oil as cocoa butter replacers in the development of sugar-free compound chocolates: Use of inulin as stabilizing agent. Food Chem., 217: 637-647.

[47] Konar N (2013) Influence of conching temperature and some bulk sweeteners on physical and rheological properties of prebiotic milk chocolate containing inulin. Eur. Food Res. Technol., 236(1): 135-143.

[48] Akyol A, Dasgin H, Ayaz A, Buyuktuncer Z and Tanju Besler H (2014) $\beta$-glucan and dark chocolate: A randomized crossover study on short-term satiety and energy intake. Nutrients, 6(9): 3863-3877.

[49] Morais Ferreira JM, Azevedo BM, Silva FGD e., Luccas V and Bolini HMA (2016) Isosweetness concentrations of sucrose and high-intensity sweeteners and antioxidant activity in white chocolate with functional properties. Int. J. Food Sci. Technol., 51(9): 2114-2122.

[50] Shoaib M, Shehzad A, Omar M et al. (2016) Inulin: Properties, health benefits and food applications. Carbohydr. Polym. 147: 444-454.

[51] Massot-Cladera M, Costabile A, Childs CE et al. (2015) Prebiotic effects of cocoa fibre on rats. J. Funct. Foods, 19: $341-352$. 
Please cite this article as

Muhammad et al. Reviews in Agricultural Science, 9: 233-248, 2021

https://dx.doi.org/10.7831/ras.9.0_233

[52] Afoakwa EO, Paterson A and Fowler M (2007) Factors influencing rheological and textural qualities in chocolate - a review. Trends Food Sci. Technol., 18(6): 290-298.

[53] Afoakwa EO, Paterson A, Fowler M and Vieira J (2008) Particle size distribution and compositional effects on textural properties and appearance of dark chocolates. J. Food Eng., 87(2): 181-190.

[54] Afoakwa EO, Paterson A, Fowler M and Ryan A (2009) Matrix effects on flavour volatiles release in dark chocolates varying in particle size distribution and fat content using GC-mass spectrometry and GC-olfactometry. Food Chem., 113(1): $208-215$.

[55] Biswas N, Cheow YL, Tan CP and Siow LF (2017) Physical, rheological and sensorial properties, and bloom formation of dark chocolate made with Cocoa Butter Substitute (CBS). LWT - Food Sci. Technol., 82: 1-36.

[56] Stubenitsky K, Aaron JI, Catt SL and Mela DJ (1999) Effect of information and extended use on the acceptance of reduced-fat products. Food Qual. and Prefer., 10(4-5): 367-376.

[57] Saputro AD, Van de Walle D, Kadivar S, Mensah MA, Van Durme J and Dewettinck K (2017) Feasibility of a small-scale production system approach for palm sugar sweetened dark chocolate. Eur. Food Res. Technol., 243(6): 955-967.

[58] Saputro AD, Van de Walle D, Kadivar S, Bin Sintang MD, Van der Meeren P and Dewettinck K (2017) Investigating the rheological, microstructural and textural properties of chocolates sweetened with palm sap-based sugar by partial replacement. Eur. Food Res. Technol., 243(10): 1729-1738.

[59] Saputro AD, Van de Walle D, Hinneh M, Van Durme J and Dewettinck K (2018) Aroma profile and appearance of dark chocolate formulated with palm sugar-sucrose blends. Eur. Food Res. Technol., 244(7): 1281-1292.

[60] de Melo LLMM, Bolini HMA and Efraim P (2009) Sensory profile, acceptability, and their relationship for diabetic/reduced calorie chocolates. Food Qual. and Prefer., 20(2): 138-143.

[61] Shah AB, Jones GP and Vasiljevic T (2010) Sucrose-free chocolate sweetened with Stevia rebaudiana extract and containing different bulking agents - effects on physicochemical and sensory properties. Int. J. Food Sci. Technol., 45(7): 1426-1435.

[62] Markey O, Lovegrove JA and Methven L (2015) Sensory profiles and consumer acceptability of a range of sugar-reduced products on the UK market. Food Res. Int., 72: 133-139.

[63] Zarić DB, Bulatović ML, Rakin MB, Krunić T, Lončarević IS and Pajin BS (2016) Functional, rheological and sensory properties of probiotic milk chocolate produced in a ball mill. RSC Adv., 6(17): 13934-13941.

[64] Foong YJ, Lee ST, Ramli N, Tan YN and Ayob MK (2013) Incorporation of potential probiotic Lactobacillus plantarum isolated from fermented cocoa beans into dark chocolate: Bacterial viability and physicochemical properties analysis. J. Food Qual., 36(3): 164-171.

[65] Lalicic-Petronijevic J, Popov-Raljić J, Obradović D et al. (2015) Viability of probiotic strains Lactobacillus acidophilus NCFM $\mathbb{R}$ and Bifidobacterium lactis HN019 and their impact on sensory and rheological properties of milk and dark chocolates during storage for 180 days. J. Funct. Foods, 15: 541-550.

[66] Belščak-Cvitanović A, Komes D, Dujmović M et al. (2015) Physical, bioactive and sensory quality parameters of reduced sugar chocolates formulated with natural sweeteners as sucrose alternatives. Food Chem., 167: 61-70.

[67] Hutchings P and Kupriyanova E (2018) Cosmopolitan polychaetes - Fact or fiction? Personal and historical perspectives. Invertebr. Syst., 32(1): 1-9.

[68] Kiumarsi M, Majchrzak D, Jäger H, Song J, Lieleg O and Shahbazi M (2021) Comparative study of instrumental properties and sensory profiling of low-calorie chocolate containing hydrophobically modified inulin. Part II: Proton mobility, topological, tribological and dynamic sensory properties. Food Hydrocoll., 110: 1-15.

[69] Kiumarsi M, Majchrzak D, Yeganehzad S, Jäger H and Shahbazi M (2020) Comparative study of instrumental properties and sensory profiling of low-calorie chocolate containing hydrophobically modified inulin. Part 1: Rheological, thermal, structural and external preference mapping. Food Hydrocoll., 104(2): 105698.

[70] Sarfarazi M and Saadatmand-tarzjan M (2020) Production of aerated chocolate and application of X-ray computed tomography and image processing in evaluating the bubbles features. Iranian Food Science and Technology Research Journal, 16(5): 525540 .

[71] Azevedo BM, Morais-Ferreira JM, Luccas V and Bolini HMA (2017) Bittersweet chocolates containing prebiotic and sweetened with stevia (Stevia rebaudiana Bertoni) with different Rebaudioside A contents: multiple time-intensity analysis and physicochemical characteristics. Int. J. Food Sci. Technol., 52(8): 1731-1738. 
[72] Aidoo RP, Afoakwa EO and Dewettinck K (2015) Rheological properties, melting behaviours and physical quality characteristics of sugar-free chocolates processed using inulin/polydextrose bulking mixtures sweetened with stevia and thaumatin extracts. LWT - Food Sci. Technol., 62(1): 592-597.

[73] Aidoo RP, Afoakwa EO and Dewettinck K (2014) Optimization of inulin and polydextrose mixtures as sucrose replacers during sugar-free chocolate manufacture - Rheological, microstructure and physical quality characteristics. J. Food Eng., 126: 35-42.

[74] Farzanmehr H and Abbasi S (2009) Effects of inulin and bulking agents on some physicochemical, textural and sensory properties of milk chocolate. J. Texture Stud., 40(5): 536-553.

[75] Aidoo RP, Appah E, Van Dewalle D, Afoakwa EO and Dewettinck K (2017) Functionality of inulin and polydextrose as sucrose replacers in sugar-free dark chocolate manufacture - effect of fat content and bulk mixture concentration on rheological, mechanical and melting properties. Int. J. Food Sci. Technol., 52(1): 282-290.

[76] Homayouni Rad A and Rasouli Pirouzian H (2021) Optimization of prebiotic sucrose-free milk chocolate formulation by mixture design. J. Food Sci. Technol., 58(1): 244-254.

[77] Haniyeh R-P, Seyed Hadi P and Sodeif A-D (2017) Rheological properties of sugar free milk chocolate: Comparative study and optimisation. Czech J. Food Sci., 35(5): 440-448.

[78] Rodriguez Furlán LT, Baracco Y, Lecot J, Zaritzky N and Campderrós ME (2017) Effect of sweetener combination and storage temperature on physicochemical properties of sucrose free white chocolate. Food Chem., 229: 610-620.

[79] Rad AH, Pirouzian HR, Toker OS and Konar N (2020) Effect of Various Bulk Sweeteners on the Survivability of Lactobacillus casei 431 in Milk Chocolate: Rheological and Sensory Properties Analysis. Curr. Pharm. Biotechnol., 21(12): $1224-1231$.

[80] Klindt-Toldam S, Larsen SK, Saaby L et al. (2016) Survival of Lactobacillus acidophilus NCFM $®$ and Bifidobacterium lactis HN019 encapsulated in chocolate during in vitro simulated passage of the upper gastrointestinal tract. LWT - Food Sci. Technol., 74: 404-410.

[81] Mandal S, Hati S, Puniya AK, Singh R and Singh K (2013) Development of synbiotic milk chocolate using encapsulated Lactobacillus casei ncdc 298. J. Food Process Preserv., 37(5): 1031-1037.

[82] Zyzlewicz D, Nebesny E, Motyl I and Libudzisz Z (2010) Effect of milk chocolate supplementation with lyophilised lactobacillus cells on its attributes. Czech J. Food Sci., 28(5): 392-406. 